\title{
Discrimination AND Victimization against gaY MEN AND LESBians IN ChILE: Two PATTERNS OR JUST ONE?
}

\author{
JaIME BARRIENTOS* AND MICHEL BOZON** \\ *Doctor in Social Psychology. Associate Professor, Escuela de Psicología, Universidad Católica del Norte. \\ Avenida Angamos 0610-Antofagasta, Chile. E-Mail: jbarrien@ucn.cl \\ **Doctor in Anthropology. Director of Research at the Institut National d'Etudes Démographiques (INED). \\ 133 Boulevard Davout, 75020 Paris, France. E-Mail: booz@ined.fr
}

\section{RESUMEN}

La marcha por el Orgullo Lésbico, Gay, Bisexual y Transgénero se realiza cada año en Santiago de Chile y aglutina a minorías sexuales, pero también a heterosexuales que asisten para apoyar a dicha población en la reinvindación de sus derechos. Específicamente, el propósito del estudio realizado fue describir a gay y lesbianas participantes en la Marcha del Orgullo desde el punto de vista de la discriminación y la victimización. Se centró solo en dicha población ya que mayoritariamente es la que asiste a la marcha y porque no existen estudios previos que comparen en el país a ambos grupos. Además, tuvo como objetivo mostrar que los hombres gay sufren más discriminación y victimización que las lesbianas. La muestra consistió en 203 gay y lesbianas mayores de 18 años. Con respecto a los resultados, la proporción de gay que reportaron haber percibido eventos de discriminación fue igual al $72.7 \%$ y $79.6 \%$ en las lesbianas. Asimismo, el $81.8 \%$ del total de los gay reportaron eventos de victimización y un $75.3 \%$ del total de las lesbianas. Se observan diferencias significativas entre gay y lesbianas, afectando solo a las últimas, en la prohibición de entrada o permanencia en lugares de entretención, discriminación ejercida por agentes de seguridad y discriminación laboral. Entre los eventos de victimización, gay informaron más burlas que las lesbianas. Se concluye que hay similaridades en los eventos de discriminación y victimización percibidos por gay y lesbianas, pero también algunas diferencias. La existencia de un patrón diferenciado entre gay y lesbianas deberá ser confirmada en futuros estudios.

Palabras clave: Hombres gay; Lesbianas; Discriminación; Victimización; Chile.

\begin{abstract}
The Lesbian, Gay men, Bisexual and Transgender (LGBT) Pride Parade takes place in Santiago (Chile) every year. It gathers sexual minorities and also heterosexuals who attend to support LGBT population rights vindication. Specifically, the objective of the study was to describe gay men and lesbians who participate in the LGBT Pride Parade, from the viewpoint of discrimination and victimization. In this sense, this study is innovating because it is based on questionnaires administered in the context of LGBT Pride Parades. In Chile, data on this issue are scarce. There are few previous studies on the topic, revealing that many LGBT people report discrimination and victimization in different situations and contexts. Nevertheless, these studies have not clearly stated the existing differences in the patterns of discrimination and victimization events that affect the different groups (for example, those that affect gay men and lesbians). So, the study focused only on this population for two reasons: first, mainly LGBT subjects attend the parade and secondly, there were no previous studies to compare both groups in the country. Second, the study also aimed at showing that gay men suffer greater discrimination and
\end{abstract}


victimization than lesbians. A non-probabilistic sample of 343 participants was collected. From this sample, 140 subjects were excluded as they did not identify themselves as gay men or lesbians, thus totaling a sample of 203 participants. There were a total of 110 gay men $(54.2 \%)$ and 93 lesbians $(45.8 \%)$, aging from 18 to 53 years $(M=24.62$ and $S D=6.62)$. Concerning results, $72.7 \%$ of gay men reported discrimination events perceived, as compared to $79.6 \%$ of lesbians. In addition, $81.8 \%$ of gay men reported victimization events, while lesbians reported $75.3 \%$. Significant differences are observed between gay men and lesbians, affecting only the latter in: prohibition to enter or stay in entertainment venues, discrimination by security guards, and discrimination at work. Among victimization events, gays reported more mockery than lesbians.

This study has various implications. One of them is the fact that an important place where gay men and particularly lesbians are discriminated is their workplace. Future studies will have to focus on investigating the impact of discrimination due to sexual orientation in a work context. In addition, future studies should further examine whether verbal mockery-type victimization and its impact on the gay men population is a common pattern of victimization toward the country's LGBT population. Likewise, it would be necessary to study whether other relevant dimensions in the country, such as social class and religion, contribute to experiencing this type of victimization.

Also, there are therapists in Chile who consider homosexuality as an illness and apply reconversive therapies, thus contributing to stigmatization and violence toward sexual minorities. Therefore, this study may contribute to the training of future therapists and health personnel assisting gay men and lesbians since sexual minorities have reported that they face various barriers that prevent them from having equal access to health services, a fact that could have a great impact on their quality of life. Finally, considering the differences in discrimination and victimization found between gay men and lesbians in Chile: Do gay men experience more discrimination and victimization events than lesbians? Are there two different patterns of discrimination and victimization or, instead, a general one that affects both gay men and lesbians in Chile? Data are not conclusive. They indicate that there are many similarities in the discrimination and victimization events perceived by gay men and lesbians, but they also reveal two different patterns. Therefore, the existence of a differentiated pattern of discrimination and victimization between gay men and lesbians should be confirmed by future studies.

Key words: Gay men; Lesbians; Discrimination; Victimization; Chile.

\section{INTRODUCTION}

In Chile, as in other countries in Latin America, the legal situation of sexual minorities has improved in the past few years (Ottoson, 2011). For example, in 2012 Chile passed an antidiscrimination law that included sexual orientation (Biblioteca del Congreso Nacional, 2013). In addition, attitudes toward sexual minorities in the western world and in Chile have gradually improved since the 1990s. For example, the Latinobarómetro and World Values Survey asked the question "How justifiable is homosexuality?", using a scale from 1: never justifiable to 10: always justifiable. The results from these surveys indi- cated that in Chile the mean for accepted homosexuality was 1.8 in 1990, compared to 5.3 in 2009. In addition, the percentage of individuals who consider that homosexuality is never justifiable has gradually decreased from $76.9 \%$ in 1990 to $11.9 \%$ in 2009 (Movimiento de Liberación e Integración Homosexual - MOVILH- , 2013).

However, discrimination, victimization, and other forms of harassment due to one's sexual orientation are still a problem in Chile (MOVILH, 2013). In Chile, as in many other western countries, sexual-orientation discrimination and victimization occur in contexts where heterosexuality is the norm (Cárdenas, Barrientos, Gómez, \& Frías-Navarro, 2012). In this context, men and women who break the social conventions of gender roles and sexuality are particularly exposed to discrimination and victimization events (Carrara, 2012). 
DISCRIMINATION AND VICTIMIZATION: SOME FINDINGS

Apart from extreme forms of discrimination and victimization reported by LGBT organizations in the past few decades, such as assassinations and hate crimes, gay men, lesbians and transgenders are affected by violence in many other ways (Caceres, Pecheny, Frasca, Raupp Rios, \& Pocahy, 2009; Ottoson, 2011). Therefore, it is essential to collect data gay men or lesbians may be treated worse or discriminated against more than other people in contexts such as the workplace, school, home, or health care services (Herek, Cogan, \& Gillis, 2002; Pelullo, Di Giuseppe, \& Angelillo, 2013). Moreover, in these contexts, gay men or lesbians may also be victims of some types of aggressions or harassment because of their sexual orientation. Gay men and lesbians could suffer different negative outcomes (e.g., physical or psychological health problems) due to this victimization.

Various studies about this discrimination and victimization have been carried out in other countries, such as the USA or Mexico (Herek, Gillis, Cogan, \& Glunt, 1997; Herek, Cogan, \& Gillis, 2002; Ortiz-Hernández \& García, 2005a). For example, one populationbased survey of adults in the U.S. found that $76 \%$ of gay men or bisexual respondents reported a lifetime of discrimination (Mays \& Cochran, 2001). Regarding victimization, in a recent Italian study using a systematic random sample, $28.3 \%$ and $11.9 \%$ self-reported at least one episode of victimization because of their sexual orientation in their lifetime and in the past year (Pelullo et al., 2013).

In Latin America, studies on the gay men and lesbian population have mainly focused on the behavior of HIV/AIDS-infected men who have sex with other men, but issues such as homophobia, which are frequently experienced by this population, have not been sufficiently analyzed (Ortiz-Hernández \& García, 2005b). In Latin America, despite the fact that more and more regional researchers and politicians are concerned about this issue, knowledge about the living conditions of gay men and lesbians is quite limited (Barrientos \& Cárdenas, 2013).
Although related research in industrialized countries provides important input, Latin American conditions are different from those of other countries, due to greater socioeconomic inequality and rigidity in characterizing gender stereotypes (Cárdenas et al., 2012).

In Chile, data on this issue are scarce. However, some studies about the discrimination and victimization of the gay men, lesbian, bisexual, and transgender populations (LGBT), using convenience samples, have been conducted in Chile in the past few years (Barrientos et al., 2010; Barrientos, Cárdenas, Díaz, \& Muñoz, 2012; MOVILH \& Fundación Progresa, 2012). These studies show that many LGBT people report discrimination and victimization in different situations and contexts. For example, a recent, non-probabilistic study carried out with 258 Chilean lesbians, gay men, bisexuals, and transgender people revealed that $52.7 \%$ of them had been individually and directly victimized (verbal and physical aggression and threats) at least once in their lives. Those most affected were transgender people (58.1\% of them reported some kind of victimization) followed by lesbians $(57.4 \%)$, gay men (49.1\%), and bisexuals (48.8\%). Furthermore, LGBT organizations, such as the Unified Sexual Minority Movement (MUMS, its acronym in Spanish) and the MOVILH, have registered discrimination and victimization events reported recently (MOVILH, 2013; MUMS, 2006). For example, MOVILH, using a compilation of reported events, has documented an increase in victimization events from 48 in 2002 to 186 in 2011 (2013).

Nevertheless, these studies have not clearly specified the existing differences in the patterns of discrimination and victimization events that affect the different groups (for example, those that affect gay men and lesbians). Research on discrimination and victim- ization of sexual minorities has found that gay men experience more extreme levels of physical violence than lesbians (Carbone-Lopez, Esbensen, \& Brick, 2010). Gay men are also more likely to be discriminated and victimized in public, including in gay-identified areas, whereas lesbians are more often discriminated and victimized in or near their homes (Aurand, 
Addessa, \& Bush, 1985). Regarding differences between gay men and lesbians, a recent meta-analysis (Katz-Wise \& Hyde, 2012) showed that gay men experience some types of victimization events (hold-up and robbery) more than women, but, in general, gender differences are small. Based on the relationship between atypical gender and victimization percentages, the authors hypothesize that men may show a more generically atypical appearance or behavior than lesbians, thus resulting in greater victimization. They also suggest that women suffer less victimization than men because sexuality between two women could be associated with their images in pornography; therefore, lesbians would be less victimized because they represent a source of excitement for heterosexual men, a fact that could normalize their minority sexual status (Katz-Wise \& Hyde, 2012).

\section{Research context: LGBT Pride Parade}

LGBT pride parades join together many gay men, lesbians, bisexuals, transgender people and heterosexuals who march for the rights of sexual minorities. These marches commemorate the disturbances that took place in the USA on June 28, 1969 in Stonewall-Inn in New York, as a response and resistance to discrimination and violence against sexual minorities. Currently, they are organized in many countries and have acquired their own meaning. They are not only manifestations of unsatisfied LGBT population needs or an opportunity for social visibility, but also a festive political event (Grupo Estudios Sobre Sexualidad, 2006). In Chile, these parades have taken place every September since 1990, and participation has increased dramatically, as shown in the 2013 parade, where about 50,000 people participated (XV version). This figure indicates that the parades provide a unique opportunity to study patterns of sexual minority discrimination and victimization. In Latin America, studies on these populations have been carried out in the LGBT parade (Assis, Carrara, Facchini, \& Ramos, 2006; Grupo Estudios Sobre Sexualidad, 2006). In Chile, only one previous study has been conducted on this issue (Barrientos et al., 2010).

Thus, the purpose of this study is to specifically describe the gay men and lesbian population that participated in the 2011-LGBT parade in Santiago, from the standpoint of discrimination and victimization. Moreover, the idea, specifically, is to show, as some previous studies suggest, that gay men suffer greater discrimination and victimization than lesbians (Katz-Wise \& Hyde, 2012).

\section{Method}

\section{PARTICIPANTS}

A non-probabilistic (convenience) sample of 343 participants was collected. From this sample, 140 were excluded, as they did not identify themselves as gay men or lesbians, leaving a sample of 203 participants. There were a total of 110 gay men $(54.2 \%)$ and 93 lesbians (45.8\%), aged from 18 to $53(M=24.62$, $S D=6.62)($ see Table 1$)$.

\section{MEASURES}

\section{SOCIO-DEMOGRAPHIC MEASURES}

Data were collected on sex, sexual selfidentification, age (participants 18 years old or younger were discarded because the age of sexual consent in Chile is 18 , and surveying people under the age of 18 requires parental consent), educational level and religion. The question for this latter variable was: "What was your religion when you were a child?" Participants were then asked about their current religion.

\section{DISCRIMINATION AND VICTIMIZATION MEASURES}

1.- Perceived discrimination events: Based on previous questions used in Brazil (Assis, Carrara, Facchini, \& Ramos, 2006), respondents were asked if they had ever experienced twelve different discrimination 
events because someone perceived them to be gay men or lesbians. Items offered two response options: Yes or No. Multiplechoice response.

2.- Victimization events: Based on previous questions used in antigay victimization and harassment studies in other countries (Herek, Gillis, Cogan, \& Glunt, 1997), respondents were asked if they had ever experienced the following aggression and harassment events because someone perceived them to be gay men or lesbians: physical abuse, insults or threats, mockery, sexual assault by a casual partner, sexual abuse, sexual harassment, and blackmail, extortion or bribery. Items offered two response options: Yes and No. Multiple-choice response.

3.- Most serious victimization events: Respondents were asked to indicate the most serious events from the seven victimization events mentioned above. One aneswer was allowed.

The following questions refer to the most serious victimization events.

1.- Place of victimization: This variable was divided into eight categories: home, work, school, public space, shop, public institution, police station, other. One answer was allowed.

2.- Perpetrators of victimization: This variable was divided into 14 categories: friend, partner, family member, neighbor, police officer, boss, co-worker, private security guard, teacher, student, schoolmate, unknown, other, and DK/NA. One answer was allowed.

3.- Reported victimization: This variable was divided into police department / court, anti-discrimination organism, mass media, NGO or LGBT group, friend, family member, partner, other, not reported, and DK / NA. One answer was allowed.

4.- Punished victimization: This variable was divided into seven categories: victimization was punished, victimization was not punished, victimization stopped, victimization did not stop, victimization increased, other, and DK / NA. Multiple-choice response.

\section{Procedure}

This study was based on questionnaires administered in the context of LGBT Pride Parades taking place in other countries of the region (CLAM, 2014). The surveys were administered by 30 volunteers involved in social science. They were recruited as interviewers, trained, and informed about possible difficulties during field work and logistics. In addition, they were provided with information on the methodological aspects of the study. All these data were included in a training manual given to each volunteer.

The questionnaire was administered faceto-face during the 2011 LGBT Pride Parade in Santiago, Chile, from 2:30 p.m. to 7:30 p.m.

The study was supported by UCN Ethics Commission. Participants gave verbal consent to participate in the study. Subjects were interviewed previous to the parade.

\section{ANALYSIS}

Descriptive analyses were performed to characterize the demographic composition and prevalence of different forms of discrimination and victimization. Next, the way these variables differed for gay men and lesbians was examined using Pearson Chi-squared tests and Analysis of Variance (ANOVA).

\section{RESULTS}

Considering the gay men and lesbian sample included, $75.9 \%$ reported perceived discrimination events and 78.8\% reported victimization events. Specifically, $72.7 \%$ of gay men and $79.6 \%$ of lesbians reported discrimination events, and $81.8 \%$ of gay men and $75.3 \%$ of lesbians reported victimization events.

\section{DISCRIMINATION EVENTS}

The discrimination events most reported by gay men and lesbians occurred in a reli- 
gious environment (36.9\%), at school (33.3\%), and in the family (33\%) (see Table 2 ).

Statistically significant differences between gay men and lesbians are observed on only three types of perceived discrimination events.

The first is not being allowed to enter or stay in a shop or entertainment venue, with lesbians being more affected than gay men: $\chi^{2}(1, N=195)=8.038, p=.005$. Second, lesbians feel more discriminated against by security guards than gay men do: $\chi^{2}(1$, $N=194)=5.519, p=.019$. Third, lesbians are more discriminated against than gay men in getting a job or being fired from a job: $\chi^{2}(1, N=194)=4.290, p=.038$.

\section{VICTIMIZATION EVENTS}

The most frequent victimization events are mockery $(64.6 \%)$ and insults or threats $(63.3 \%)$ (see Table 3). There are significant differences between gay men $(71 \%)$ and lesbians $(57.1 \%)$ only on mockery: gay men report more mockery than lesbians: $\chi^{2}(1$, $N=198)=4.418, p=.042$.

Since the majority of the gay men and lesbians have suffered from insults, threats and mockery, it is not surprising that these events also appear as the most serious ones reported. Thus, the most serious victimization events (not considering the time of occurrence) are insults or threats $(36.2 \%)$, followed by mockery $(24.8 \%)$. The most serious victimization events reported by gay men are insults and threats $(35.3 \%)$, mockery $(30.6 \%)$, and sexual harassment $(16.5 \%)$, whereas those reported by lesbians are insults and threats $(37.5 \%)$, mockery (17.2\%), and physical aggression $(17.2 \%)$. Furthermore, although insults, threats and mockery are important for both groups, an important difference is observed between gay men and lesbians: gay men report sexual harassment as a serious victimization event, whereas lesbians report physical victimization as a serious event. However, there were no statistically significant differences between gay men and lesbians regarding the most serious victimization events.
Places where gay men and lesbians are frequently victimized due to their sexual identity are, first, public places (44.1\%), followed by school $(25 \%)$ and home $(15.1 \%)$. In the case of gay men, public places are first (39.5\%), followed by school (31.4\%), whereas in the case of lesbians, public places are also first (50\%), but followed by home (18.4\%). No statistically significant differences in the victimization sites were observed between gay men and lesbians.

Coinciding with the most frequent places of victimization, the perpetrators of victimization are frequently unknown individuals $(38.5 \%)$, schoolmates $(19.9 \%)$, family members $(10.9 \%)$, and friends $(9.6 \%)$; that is, the latter three were close to the victims. In the case of gay men, the authors of victimization are mostly unknown (38.6\%), followed by schoolmates $(29.5 \%)$ and friends and acquaintances $(12.5 \%)$, whereas in the case of lesbians, the main authors of victimization are also unknown (38.2\%), followed by family members $(17.6 \%)$. Although no statistically significant differences in the perpetrators of victimization are observed between gay men and lesbians, the figures above confirm the data on places of victimization.

Results show that $21.4 \%$ of gay men and lesbians who are victimized because of their sexual orientation do not report these events, indicating that they hide them rather than facing them. Although all the gay men and lesbians interviewed have revealed their sexual orientation to someone, revelation is not necessarily associated with reporting discrimination and victimization events. In addition, gay men and lesbians share these experiences with friends $(49.4 \%)$, family members $(32.5 \%)$, and partners $(16.2 \%)$. Only $7.1 \%$ denounce them to the police or in court. Most gay men report these experiences to friends $(50 \%)$ and family members $(24.4 \%)$, but $22.1 \%$ do not report them; on the other hand, lesbians report them to friends $(48.5 \%)$ and family members $(42.6 \%)$, but $20.6 \%$ do not report them. Although no statistically significant differences are found between gay men and lesbians regarding to whom they report the victimization, some differences are observed: whereas gay men report it more frequently to friends and 
family members, lesbians do so less frequently. Lesbians report victimization by family members more frequently.

Finally, the violence stopped in only $2.7 \%$ of the victimization events reported, while $18.9 \%$ were punished in some way. Results also reveal that $36.5 \%$ of victimization events were not punished in the case of both gay men (36.6\%) and lesbians (36.4\%). No statistically significant differences were observed between gay men and lesbians regarding punishment of the most serious victimization.

\section{Discussion}

First of all, the results indicate that an important proportion of those surveyed, both gay men and lesbians, perceive discrimination and victimization events, and that, in some cases these events affect both groups similarly (for example, insults and threats). However, the findings also indicate that there are some differences between the two groups in the perception of discrimination and victimization events. Therefore, these findings could suggest that these events may not be equally distributed between gay men and lesbians.

Regarding perceived discrimination events, the results indicate significant differences between gay men and lesbians. Lesbians report perceiving more discrimination than gay men in three situations: entering or staying in a shop or entertainment venue, having experienced discrimination by security guards, and, finally, having been discriminated against in getting a job or being fired from a job.

In Chile, in large cities like Santiago, gay men and lesbians may go to public places more frequently, thus exposing themselves to more discrimination. Therefore, the city favors freedom to live their own lives, but, at the same time, it exposes subjects to more discrimination and victimization. In Santiago and other cities in the country, security guards control the entrances to many public places, and they maintain the security in many different contexts; the number of guards has increased significantly in recent years in Chile (Gobierno Regional Metropolitano de Santiago, 2012). Security guards are generally retired police officers or young people who recently finished their military service. According to a recent report, private security in Chile is still considered by many as a continuity of an armed forces career (Centro de Investigación Periodística - CIPER -, 2013). In both cases, retired police officers or young people who have done their military service, these men perform a type of hegemonic masculinity (Connell \& Messerschmidt, 2005), and they often act as guardians of this type of masculinity. Therefore, based on prior studies, as gay men would be expected to show a more atypical gender appearance or behavior that does not conform to the gender role expectations for men, they could experience more victimization than lesbians (Katz-Wise \& Hyde, 2012). However, the data do not corroborate this greater victimization of gay men. Thus, it is likely that these men (security guards) act out against lesbians in an effort to control and safeguard the fulfillment of the gender roles expected for women in Chilean culture, like those of mother and wife (Barrientos, 2010). With the recent anti-discrimination law passed in 2012, these types of events will probably decline, as this law will protect sexual minorities from discriminatory actions like the ones performed by the guards. Furthermore, some studies suggest that while appearance is fundamental to sexual identity, it is also potentially problematic within the broader heterosexist society (Huxley, 2013). Research shows that many lesbians actively adopt particular appearance norms after they come out, in order to be 'read' as lesbians (Krakauer \& Rose, 2002). Some types of discrimination (for example: at work, in a shop or local venues) may be related to physical appearance and be carried out by security guards, and this type of discrimination could affect the lesbian population because their image probably creates more hostility and explicit rejection in a very sexist culture like Chile (Cárdenas et al., 2012). However, future studies should examine these discrimination events to confirm that they occur and affect the country's lesbians.

In Latin America, lesbians suffer discrimination in the workplace (ADEIM et al., 2006). Moreover, various studies indicate that in Chile, 
women still suffer from greater job discrimination (Peña, 2011). In the case of lesbians, this could correspond to a double type of discrimination: first for being women and, second, for being lesbians.

Another interesting finding about the discrimination that affects both gay men and lesbians in Chile is that many subjects reported discrimination in a religious environment. In Chile, the church is one of the main institutions that reproduce and sustain the hegemonic hetero-patriarchal model, linking non-heterosexuality to abnormality and giving heterosexual men a place of privilege and moral supremacy (Ruiz, 2011).

Regarding the differences in victimization events between gay men and lesbians, the results showed that gay men are more likely to suffer verbal mockery-type victimization events than lesbians, which contradicts previous findings indicating that gay men experience more extreme levels of physical violence (Carbone-Lopez et al., 2010) and certain types of victimization events (hold-up and robbery) more than women (Katz-Wise \& Hyde, 2012). One possible explanation for this finding is that verbal aggression is common toward men who transgress the country's gender role expectations (Barrientos, Salinas, Rojas, \& Meza, 2011). Homophobic terms like faggot have a rich developmental history and play a central role, for example, in adolescent male peergroup dynamics (Plummer, 2001). Jokes about those who do not comply with gender role expectations are frequent among men and in male social contexts on a national scale (Barrientos, Salinas, Rojas, \& Meza, 2011). Another relevant finding is that from the point of view of gay men and lesbians, the victimization events that are perceived as the most serious and important in their lives are not physical aggressions, which would be the case of gay men according to previous studies (Carbone-Lopez et al., 2010), but rather insults, threats and jokes. This finding is very important and might not be well-understood outside of the Chilean context. In our country, verbal violence is frequent and practiced toward anyone who is different, and it is a highly-reported form of perceived discrimination by diverse discriminated groups
(Merino, Quilaqueo \& Saiz, 2008). Moreover, as some authors have pointed out (Parker, 2001, p. 78), language is a "pernicious and powerful tool", prejudice can have both an implicit and explicit effect on language, and language plays a critical role in every form of prejudice (Collins \& Clément, 2012). Likewise, anti-gay men and lesbian language is one of many mechanisms through which heterosexism is enacted; it communicates hostility toward gay men and lesbians and contributes to creating an unwelcoming and unsafe environment for them (Burn, 2000).

Moreover, the data reveal a greater presence of sexual harassment of gay men than lesbians, although these data are not statistically significant. A recent study in Chile using a probabilistic sample shows that, in a general population over 18 years old, $7.9 \%$ of men reported some kind of sexual violence during childhood or adolescence, $6.6 \%$ reported that someone had touched their genitals or buttocks, and $4.3 \%$ revealed non-consensual sexual relations (forced sex) (Aguayo, Correa, \& Cristi, 2011). The aforementioned study shows that the Chilean concept of manhood is associated with male heterosexuality, since 9 out of 10 men $(88.6 \%)$ and women $(88.7 \%)$ interviewed agreed with the statement a real man has sexual relations only with women (Aguayo et al., 2011). Future studies should examine whether this is a common pattern shared by Chilean gay men, as a recent study about sexual violence in young men and women in Chile indicated that women reported a significantly greater prevalence of sexual victimization than men $(31.2 \%$ compared to $20.5 \%$, from the age of 14 on; and $17.1 \%$ compared to $11.6 \%$, in the past 12 months) (Lehrer, J.A., Lehrer, E.L., \& Oyarzún, 2009).

Other interesting findings indicate that although most of the events reported occurred in public places, which are associated with less punishment, data on the home as a context for violence and discrimination are relevant because homes should provide safety and protection (Herrera, 2007). For example, this study reveals some specifications about victimization toward lesbians, showing, as in other studies, that one of the relevant contexts of their vic- 
timization is daily family life. The family's rejection of sexuality and their victimization practices due to sexual orientation are among the most salient stressors facing LGBT youths (D’Augelli, 2002).

\section{LIMITATIONS}

This study has limitations. While the LGBT pride parade provides a unique opportunity to collect data from the LGBT population, as the community tends to be concentrated in one area for a brief period of time, there are also a number of assumptions being made about the data. To begin with, this sample is not representative of the Chilean LGBT community, as a significant number of self-identified gay men or lesbian individuals do not attend the pride parade for a number of reasons, including possible fear of victimization. Additionally, this sample fails to include individuals who may not have come out and, therefore, do not attend the parade. These individuals may be either more or less susceptible to victimization, depending on the arguments. Finally, individuals who attend the pride parade may express their sexuality differently, perhaps more openly than other LGBT individuals, and this expression may make them vulnerable to discrimination and/or victimization. It may also make them more aware of discrimination and/or victimization experiences.

A second limitation has to do with the lack of additional measures, such as gender identity measures regarding masculinity or femininity, or different types of variables linked to minority stress (Meyer, 1995). In addition to sexual orientation, gender identity and gender expression can greatly impact the likelihood of discrimination and/or victimization (Sandfort, Melendez, \& Diaz, 2007), especially in the social context of Chile, which values traditional strict gender roles. Finally, the third limitation is the lack of multivariate analyses.

\section{RESEARCH IMPLICATIONS}

An important place where gay men and, particularly lesbians, are discriminated is at workplaces. Future studies will have to investigate the impact of discrimination due to sexual orientation in a work context.

Future studies should further examine whether verbal mockery-type victimization and its impact on the gay men population is a common pattern of victimization toward the country's LGBT population. Likewise, it would be necessary to study whether other relevant dimensions in the country, such as social class and religion, contribute to experiencing this type of victimization.

Considering the type of context in Chile, where heterosexism is the norm, it would be necessary to examine atypical gender roles and their impact on discrimination and victimization in greater depth.

This study used a convenience sample of gay men and lesbians. Future studies should include other types of samples, such as Respondent Driven Samples or other similar samples (Cárdenas \& Yañez, 2012), to collect information about discrimination and victimization in the Chilean LGBT population.

This study used only some types of measures associated with discrimination and victimization. Future studies measuring minority stress would make it possible to control internalized homophobia, which may increase or decrease an individual's sensitivity to perceived victimization and / or discrimination.

This study was descriptive. Future studies should include new variables and models predicting discrimination or victimization outcomes. Finally, future studies should examine life-long issues, such as violence toward the LGBT population, in depth. Thus, longitudinal studies should be conducted to understand violence toward this population better (Institute of Medicine, 2011).

Clinical AND POLITICAL IMPLiCATIONS

This paper addresses discrimination and victimization toward gay men and lesbians in Chile. Considering the impact of homophobia on people's lives (Meyer, 1995), the impact of this violence on physical and mental health and gay men and lesbians' quality of life should be studied in depth. 
The design of public policies in health and other areas must include data from populations affected by violence. For example, the gay men population and other groups are considered HIV vulnerable. Current data from Latin America and the Caribbean confirm this vulnerability (Cáceres, 2002), and violence could even increase it (Parker, 2012).

Therefore, progress in describing and characterizing violence and understanding possible discrimination and victimization patterns toward gay men and lesbians may be useful for focusing efforts to decrease vulnerability to risk and violence, as well as increasing quality of life.

Finally, in Chile, there are still therapists who consider homosexuality as an illness and apply reconversive therapies, thus contributing to stigmatization and violence toward sexual minorities (Barrientos \& Cárdenas, 2013). Therefore, this study may contribute to the training of future therapists and health personnel attending to gay men and lesbians, since sexual minorities have reported that they face various barriers that prevent them from having equal access to health services, a fact that could have a great impact on their quality of life (Institute of Medicine, 2011).

An antidiscrimination law that includes sexual orientation was passed in 2012. In this context, the parade is one of the few collective oc- casions for Chile's citizens to express other sexualities different from the heterosexual norm, thus becoming a social and political opportunity to present their demands and unrest.

Therefore, the data from this study could be used to direct public policies, policy makers, social scientists, the LGBT movement, and legislation on these issues, integrating the views of the population affected by the discriminatory treatment.

\section{Conclusions}

Considering the differences in discrimination and victimization found between gay men and lesbians in Chile: Do gay men experience more discrimination and victimization events than lesbians? Are there two different patterns of discrimination and victimization or, instead, a general one that affects both gay men and lesbians in Chile? The data are not conclusive. They indicate that there are many similarities in the discrimination and victimization events perceived by gay men and lesbians, but they also reveal two different patterns. Therefore, the existence of a differentiated pattern of discrimination and victimization between gay men and lesbians should be confirmed by future studies. 


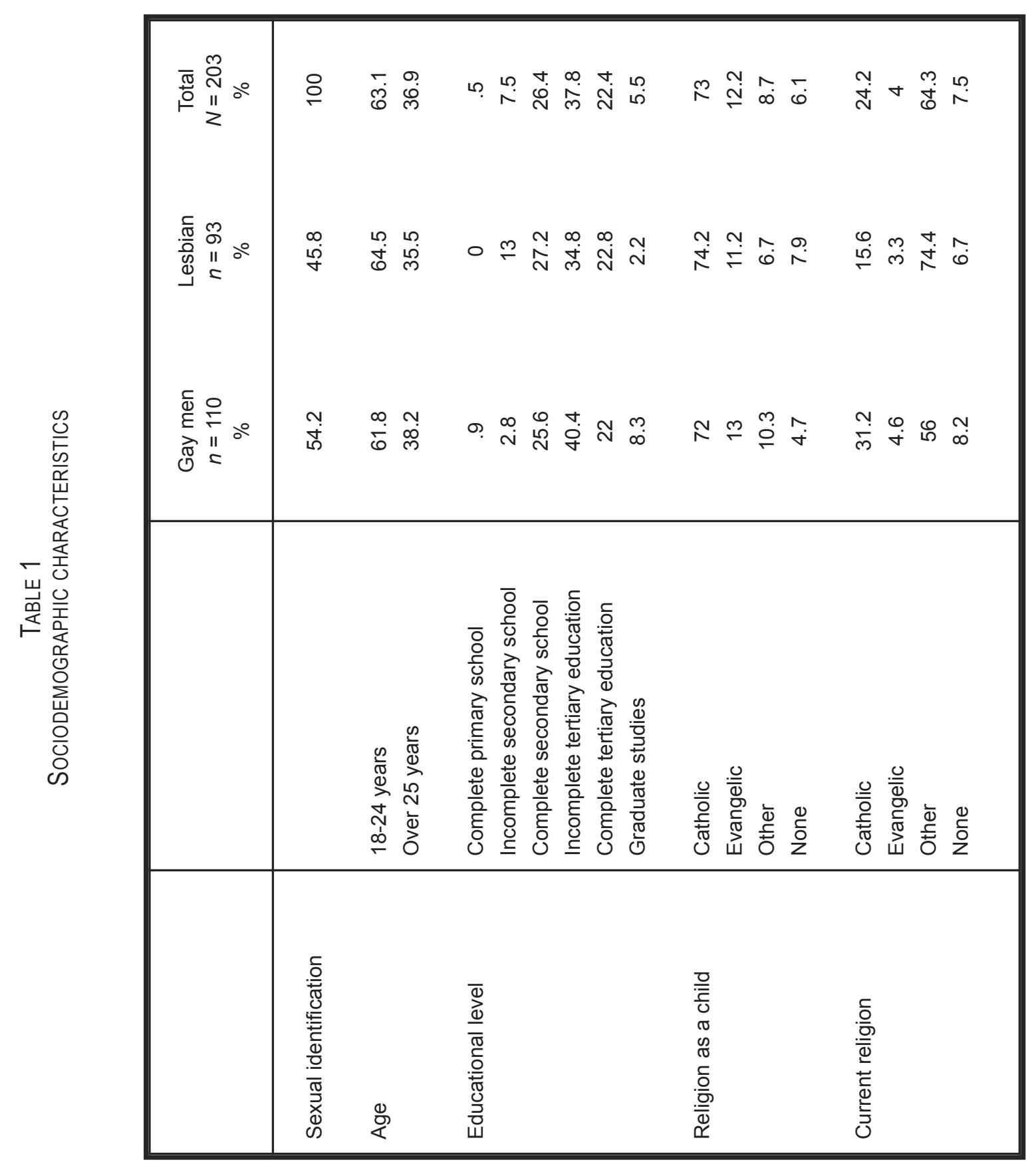


Barrientos and Bozon

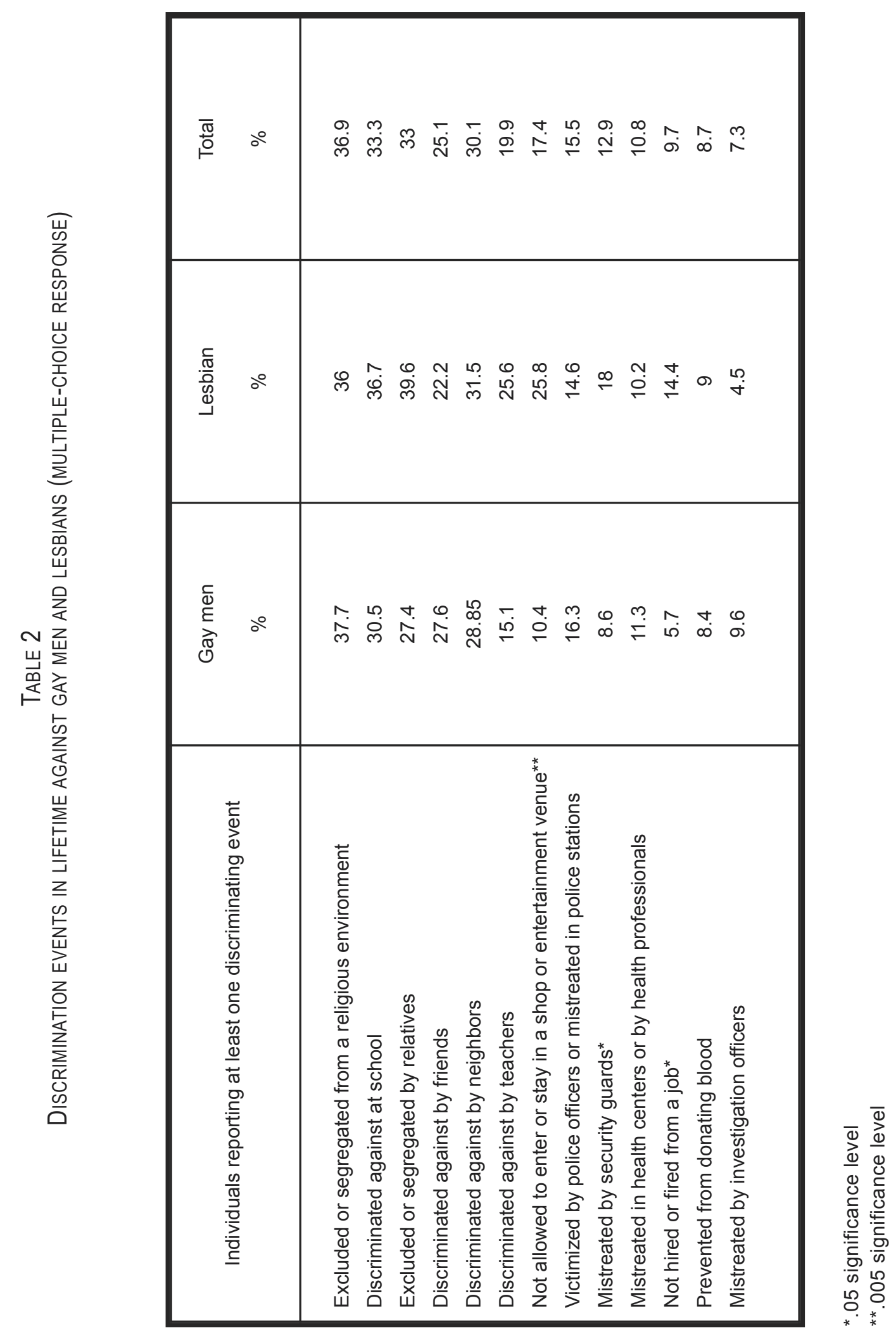




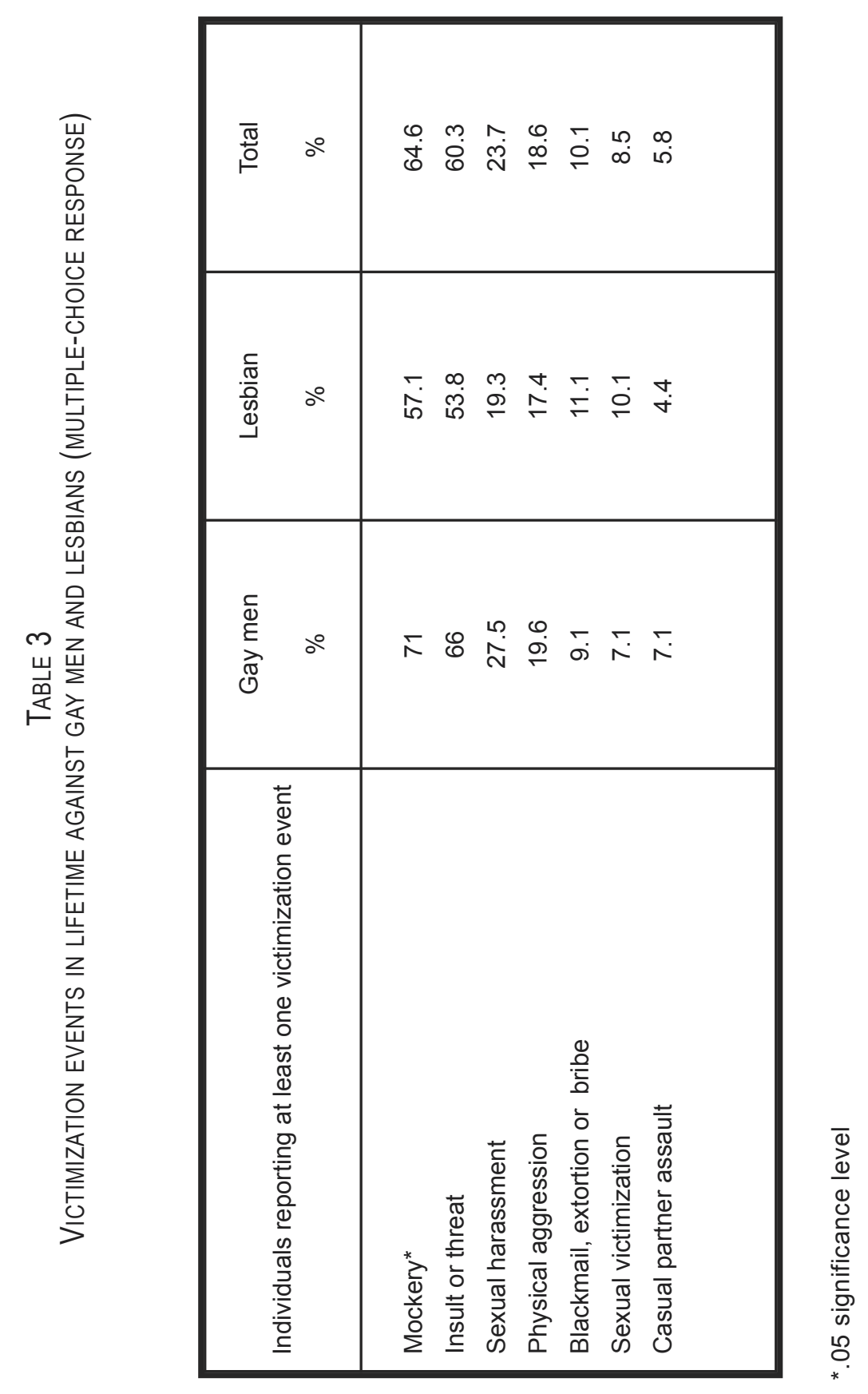




\section{REFERENCES}

ADEIM-Simbiosis, Artemisa, Cattrachas, Criola, IGLHRC, \& Red Nosotras (2006). La invisibilidad aseguraba el puchero. Lesbianas y discriminación laboral en Colombia, Bolivia, Brasil, Honduras y México [Invisibility confirmed food. Lesbians and discrimination at work in Colombia, Bolivia, Brazil, Honduras, and Mexico]. Buenos Aires: Comisión Internacional de Derechos Humanos para Gays y Lesbianas (IGLHRC).

Aguayo, F., Correa, P., \& Cristi, P. (2011). Encuesta IMAGES Chile. Resultados de la Encuesta Internacional de Masculinidades y Equidad de Género [Chile IMAGES Survey. Results of the International Survey of Masculinities and Gender Equity]. Santiago: Cultura Salud / EME.

Assis, J., Carrara, S., Facchini, R., \& Ramos, C. (2006). Política, directos, violencia e homossexualidade. Pesquisa $9^{a}$ parada do orgulho GLBT-Sâo Paulo 2005 [Politics, rights, violence, and homosexuality. Questionnaire on the 9th LGBT Pride Parade in Sao Paolo, 2005]. Rio de Janeiro: CEPESC.

Aurand, S.K., Addessa, R. \& Bush, C. (1985). Violence and discrimination against Philadelphia lesbian and gay people. Philadelphia: Lesbian and Gay Task Force.

Barrientos, J. (2010). Sexual initiation for heterosexual individuals in northern Chile. Sexuality Research \& Social Policy, 7(1), 37-44. http:// dx.doi.org/10.1007/s13178-010-0007-0

Barrientos, J., Cárdenas, M., Díaz, J., \& Muñoz, F. (2012). Derechos, políticas, violencia y diversidad sexual. Segunda encuesta marcha por la diversidad sexual-Santiago 2011 [Rights, politics, violence, and sexual diversity. Second survey on the sexual diversity parade in Santiago 2011]. Santiago: UCN / MUMS.

Barrientos, J. \& Cárdenas, M. (2013). Homofobia y calidad de vida de gay y lesbianas: Una mirada psicosocial [Homophobia and quality of life in gay men and lesbians: A psychosocial view]. Psykhe, 22(1), 3-14. http://dx.doi.org/ 10.7764/psykhe.2013.22.10

Barrientos, J., Salinas, P., Rojas, P., \& Meza, P (2011). Gender relations and masculinity in northern Chile mining areas: Ethnography in schoperías. Etnográfica, 15(3), 413-440.

Barrientos, J., Silva, J., Catalán, S., Gómez, F., \& Longueira, J. (2010). Discrimination and victimization: Parade for lesbian, gay, bisexual, and transgender (LGBT) pride, in Chile. Journal of Homosexuality, 57, 760-775. http:// dx.doi.org/10.1080/00918369.2010.485880

Biblioteca del Congreso Nacional (2013). Ley núm. 20.609 [Law ${ }^{\circ}$ 20.609]. Retrieved July 22, 2013 from http://www.leychile.cl/Navega r?idNorma $=1042092$

Burn, S.M. (2000). Heterosexuals" use of "fag" and "queer" to deride one another: A contributor to heterosexism and stigma. Journal of Homosexuality, 40(2), 1-11. http://dx.doi.org/ $10.1300 / J 082$ v40n02_01

Cáceres, C.F. (2002). HIV among gay and other men who have sex with men in Latin America and the Caribbean: A hidden epidemic? AIDS, 16 (Suppl. 3), S23-33. http://dx.doi.org/10.10 97/00002030-200212003-00005

Cáceres, C., Pecheny, M., \& Terto, V. (2002). AIDS and Male-to-Male Sex in Latin America: Vulnerabilities, strengths and proposed measures- Perspectives and reflections from the point of view of public health, social sciences and activism. Lima: UPCH / UNAIDS.

Carbone-Lopez, K., Esbensen, F.A., \& Brick, B.T. (2010). Correlates and consequences of peer victimization: Gender differences in direct and indirect forms of bullying. Youth Violence and Juvenile Justice, 8(4), 332-350. http://dx.doi. org/10.1177/1541204010362954

Cárdenas, M., Barrientos, J., Gómez, F., \& Frías Navarro, D. (2012). Attitudes toward gay men and lesbians and their relationship with gender role beliefs in a sample of Chilean university students. International Journal of Sexual 
Health, 24(3), 226-236. http://dx.doi.org/10. 1080/19317611.2012.700687

Cárdenas, M. \& Yañez, S. (2012). Nuevas formas de muestreo para minorías y poblaciones ocultas: Muestras por encuestado conducido en una población de inmigrantes sudamericanos [New forms of sampling for minority and hidden populations: Respondent samples conducted in a South American immigrant population]. Universitas Psychologica, 11(2), 571-578.

Carrara, S. (2012). Discrimination, policies, and sexual rights in Brazil. Cadernos de Saúde Pública, 28(1), 184-189. http://dx.doi.org/doi. org/10.1590/S0102-311X2012000100020

Centro de Investigación Periodística -CIPER(2013). Seguridad privada: El millonario negocio de explotar el miedo [Private security. The million-worth business to exploit fear]. Retrieved on July 22, 2013, from http://ciperchile.cl/2009/03/12/seguridad-privada-el-millonario-negocio-de-explotar-el-miedo/

CLAM -Centro Latinoamericano de Sexualidad y Derechos Humanos- (2014). Política, derechos, violencia y homosexualidad [Politics, rights, violence, and homosexuality]. Retrieved on July 22, 2013, from http://www.clam.org. br/es/pesquisas/conteudo.asp?cod $=279$

Collins, K.A., \& Clément, R. (2012). Language and prejudice: Direct and moderated effects. Journal of Language and Social Psychology, 31, 376. http://dx.doi.org/10.1177/0261927 X1 2446611

Connell, R.W. \& Messerschmidt, J.W. (2005). Hegemonic masculinity: Rethinking the concept. Gender Society, 19, 829-859. http://dx. doi.org/10.1177/0891243205278639

D'Augelli, A.R. (2002). Mental health problems among lesbian, gay, and bisexual youths ages 14 to 21. Clinical Child Psychology and Psychiatry, 7, 439-462. http://dx.doi.org/10.1177/ 1359104502007003010

Gobierno Regional Metropolitano de Santiago (2012). Estudio de Oferta de Servicios de Seguridad Privada en la Región Metropolitana de
Santiago [Study on private security service supply in the Metropolitan Region, Santiago]. Retrieved on July 22, 2013, from: http://www. gobiernosantiago.cl/Estudio\%20Oferta\%20Se guridad $\% 20$ Privada $\% 20$ RMS/Informe $\% 20$ Fin al_Estudio\%20Seguridad\%20Privada\%20RM S.pdf

Grupo de Estudios sobre Sexualidades (2006). Sexualidades, politica y violencia [Sexualities, politics and violence]. Buenos Aires: Editorial Atropofagia.

Herek, G.M., Gillis, R., Cogan, J., \& Glunt, E. (1997). Hate crime victimization among lesbian, gay, and bisexual adults: Prevalence, psychological correlates, and methodological issues. Journal of Interpersonal Violence, 4(12), 195-215. http://dx.doi.org/10.1177/08862609 7012002003

Herek, G.M., Cogan, J., \& Gillis, J. (2002). Victim experiences in hate crimes based on sexual orientation. Journal of Social Issues, 58(2), 319339. http://dx.doi.org/10.1111/1540- 4560.002 63

Herrera, F. (2007). Construcción de la identidad lésbica en Santiago de Chile [The construction of lesbian identity in Santiago, Chile]. Universum, 22(2), 151-163.

Huxley, C. (2013). Lesbian and bisexual women's experiences of sexuality based discrimination and their appearance concerns. Psychology \& Sexuality, 4(1), 7-15. http://dx.doi.org/10.1080/ 19419899.2013.748239

Institute of Medicine [IOM]. (2011). The health of lesbian, gay, bisexual, and transgender people: Building a foundation for better understanding. Washington, DC: The National Academies Press.

Katz-Wide, S. \& Hyde, J. (2012). Victimization experiences of lesbian, gay, and bisexual individuals: A meta-analysis. Journal of Sex Research, 49(2-3), 142-167. http://dx.doi.org/1 0.1080/00224499.2011.637247

Krakauer, I.D. \& Rose, S.M. (2002). The impact of group membership on lesbians' physical ap- 
pearance. Journal of Lesbian Studies, 6, 31-43. http://dx.doi.org/10.1300/J155v06n01 04

Lehrer, J.A, Lehrer, E.L., \& Oyarzún, P.B. (2009). Violencia sexual en hombres y mujeres jóvenes en Chile: Resultados de una encuesta (año 2005) a estudiantes universitarios [Sexual violence in young men and women in Chile: Results from a 2005 survey of university students]. Revista Médica de Chile, 137(5), 599608. http://dx.doi.org/org/10.4067/S0034-988 72009000500002

Mays, V.M. \& Cochran, S.D. (2001). Mental health correlates of perceived discrimination among lesbian, gay, and bisexual adults in the United States. American Journal of Public Health, 91, 1869-1876. http://dx.doi.org/10.2 105/AJPH.91.11.1869

Merino, M.E., Quilaqueo, D., \& Saiz, J.L. (2008). Una tipología del discurso de discriminación percibida en mapuches de Chile [Discursive typology of perceived discrimination against mapuches in Chile]. Revista Signos, 41, 67, 279-297. http://dx.doi.org/10.4067/S0718-09 342008000200011

Meyer, I. (1995). Minority stress and mental health in gay men. Journal of Health and Social Behavior, 36, 38-56.

Movimiento de Integración y Liberación Homosexual (2013). XI Informe Anual de Derechos Humanos de la Diversidad Sexual en Chile, Hechos 2012 [XI Annual Report on the Human Rights of Sexual Diversity in Chile, Facts 2012]. Santiago, Chile: Autor. Retrieved on October 22, 2012, from http://www.movilh.cl/ documentacion/XI_Informe_de_DHH_Movilh _Hechos_2012.pdf

Movimiento de Integración y Liberación Homosexual \& Fundación Progresa (2012). Encuesta sobre discriminación de las minorías sexuales [Questionnaire on sexual minority discrimination]. Santiago, Chile: Autores. Retrieved on July 22, 2012, from http://www.emol.com/docu mentos/archivos/2011/10/06/20111006134740.p df
Movimiento Unificado de Minorías Sexuales. (2006). Informe de Derechos Humanos y Discriminación 2006 [2006 report on human rights and discrimination]. Retrieved on October 22, 2012 from http://www.mums.cl/sitio/

Ortiz-Hernández, L. \& García, M.I. (2005a). Efectos de la violencia y la discriminación en la salud mental de bisexuales, lesbianas y homosexuales de la Ciudad de México [Effects of violence and discrimination on the mental health of bisexuals, lesbians, and gays in Mexico City]. Cadernos de Saúde Pública, 21(3), 913925. http://dx.doi.org/10.1590/S0102-311X20 05000300026

Ortiz-Hernández, L. \& García, M. (2005b). Opresión internalizada y prácticas sexuales de riesgo en varones homo-y bi-sexuales de México [Internalized oppression and high-risk sexual practices among homosexual and bisexual males, Mexico]. Revista de Saúde Pública, 39 (6), 956-964. http://dx.doi.org/10.1590/S003489102005000600014

Ottoson, D. (2011). ILGA Reports. A world survey of laws prohibiting same sex activity between consenting adults. Retrieved on October 22, 2012, from, http://old.ilga.orgStatehomopho biaGA_State_Sponsored_Homophobia_2011. pdf

Parker, J. (2001). Language: A pernicious and powerful tool. The English Journal, 19(2), 74-78.

Parker, R. (2012). Stigma, prejudice and discrimination in global public health. Cadernos de Saúde Pública, 28(1), 164-169. http://dx.doi. org/10.1590/S0102-311X2012000100017

Pelullo, C.P., Di Giuseppe, G., \& Angelillo, I.F. (2013). Frequency of discrimination, harassment, and violence in lesbian, gay men, and bisexual in Italy. PLOS ONE, 8(8), e74446. http:/ /dx.doi.org/10.1371/journal.pone.0074446

Peña, T. (2011). La mujer en Chile, una carga pesada [Women in Chile, a heavy load]. Retrieved on July 22, 2013 from, http://www.observ atoriogeneroyliderazgo.cl/index.php/las-noticias/4980-la-mujer-en-chile-una-carga-pesada 
Plummer, D.C. (2001). The quest for modern manhood: Masculine stereotypes, peer culture and the social significance of homophobia. Journal of Adolescence, 24, 15-23. doi.org/10.1006/jad o.2000.0370

Ruiz, N. (2011). Significaciones imaginarias sociales sobre la homosexualidad en la prensa escrita de Venezuela [Imaginary social significances of homosexuality in the written press of Vene- zuela]. Psicoperspectivas. Individuo y Sociedad, 10(2), 202-223. http://dx.doi.org/10.5027/ psicoperspectivas-Vol10-Issue2-fulltext-152

Sandfort, T.G.M., Meléndez, R.M., \& Diaz, R.M. (2007). Gender nonconformity, homophobia, and mental distress in latino gay and bisexual men. Journal of Sex Research, 44(2), 181-189. http://dx.doi.org/10.1080/00224490701263819

Escuela de Psicología Universidad Católica del Norte Antofagasta - Chile Institut National d'Etudes Démographiques (INED)

Paris - France

Fecha de recepción: 9 de abril de 2014 Fecha de aceptación: 20 de agosto de 2014 
